\title{
The Role Of Family Altar And Evangelism In Church Growth
}

\author{
James Siregar \\ \{jamessiregar@yahoo.com\} \\ Postgraduate Program, Pelita Kebenaran School of Theology ${ }^{1}$
}

\begin{abstract}
Evangelism, as it is known, is an indispensable part of church and Christianity. Meanwhile, with the increasing number of churches everywhere and with the growing number of congregations, especially in churches in the city, it is important to observe whether the churches continue to carry out or have evangelistic zeal as stated by Heath that the situation "cannot quell joyful news that flows from a passionate heart. "It could be that the church is focused on serving itself internally in order to pay attention to the welfare and comfort of the people. It cannot be denied that the church really needs to pay attention to the service of the people, even services that are holistic. With the existence of such a holistic service concept, it is precisely diverting more attention to service to the church congregation. It is conceivable that this requires resources and if the church does not carefully maintain balance, it is not impossible that the church will forget evangelism. Moreover, if the church has mobilized its resources for the ministry of the congregation, the church may be exhausted and lose enthusiasm for carrying out the responsibility for evangelism.
\end{abstract}

Keywords: Evangelism, cell group, Family Altar, church growth

\section{Introduction}

In the midst of the general condition of the church today, it can be observed that it is possible that many people consider evangelism to be a burden not as a passion. Evangelism itself is truly the passion of the Lord Jesus. According to Christian theology, Jesus is the one who initiated earth evangelism and He demonstrated how evangelism was carried out to be followed by His followers or disciples. In the course of His ministry, the Lord Jesus showed that evangelism is a source of passion in life. Once when Jesus evangelized a Samaritan woman, he later explained to his disciples that "my food is to do the will of God". Based on this, it can be said that the act of evangelism for Him is not something tiring, but it awakens His heart. It was said like that because evangelism was carried out like "eating" activities which gave new energy or strength. Thus evangelism cannot be regarded as a burden or a kind of obligation, but rather that evangelism is something that is God's will and brings meaning and strength to the life of Christians. So in relation to the church, it can be questioned whether in fact the churches of the present day view evangelism as a heavy burden or a burden and responsibility, while the Lord Jesus regards it as something refreshing and strengthening.

On the other hand it can also be observed that there are temporary churches that have evangelistic activities or special programs in charge of the section but have not run it properly. At present there are many places to get training and gain knowledge and even knowledge about evangelism. Churches in Korea, for example, send lecturers or professors throughout the world and teach the science of Mission and Evangelism. In America there are also theological 
colleges which are called centers of mission and evangelistic studies that offer various forms of resources both insight, data and information that are expected to support the progress of evangelism. However, even if a church establishes links with institutions that offer resources for evangelism, it is not certain that a church can immediately become effective in carrying out evangelism. It is recognized that insights and knowledge are certainly needed for the development of evangelism, but that insight and knowledge will not be effective without a wisdom in its implementation in the field due to the varied conditions in the field both in terms of customs, culture, habits or lifestyle local community. So to achieve this effectiveness tenacity is needed and carried out in a relatively long period of time and adjustments after adjustments until later found a suitable and distinctive model for a particular area will then be able to taste a fruit or the results of the evangelism.

\section{Research Method}

This study focuses on Family Altars and evangelism in churches in the city of Medan. This research is descriptive in that it seeks to describe, collect, compile, and interpret existing data, followed by examining factors related to the phenomenon of gadget addiction in the city of Medan. Data is taken from interviews church leaders and church activists. This study uses the behaviorism personality theory.

\section{Results}

Church servants through cell groups are a pattern that reflects the pattern of service that existed in the early church. In the Indonesian Bethel Church Medan Plaza the service of a cell group is called Family Altar (in Indonesian means "family altar") and is often abbreviated as "FA". This activity is held once a week and generally on Friday nights, although there are also those who hold it on other days and times according to the congregation and the administrators who run the FA. The FA at GBI Medan Plaza has been around since the church was founded in 1993 in the city of Medan and since then the FA has gone through several forms of change. However, the core of the FA itself has not changed, namely the activity of singing praises, worshiping, preaching the Word of God briefly, and praying for one another. Accordingly, the pattern contained in the FA strongly reflects the pattern of worship activities that existed in the early church which was full of atmosphere of togetherness and family. Therefore it is very appropriate for the activity to use the word "Family", which is family. This pattern of worship is quite a strong pattern because, like the conditions in China, the oppressed church can survive without appearing on the surface or underground church that takes the form of the FA. That is, if at one time the church faced severe persecution, the church would still be able to walk with a model of worship activities in homes with that family atmosphere and togetherness.

The pattern of Family Altar service can also be seen as a forum to accommodate the stages of the ummah's growth. Spiritual life is something that has stages, namely the initial stage and the stage of growth. The initial stage is where someone repents or is born again. This stage needs to be followed up by the growth stage and the place that is considered very suitable for growth is the FA. After repentance and being born again there is much more that 
must be learned and experienced by a congregation. There are so many things that someone can learn from other people around him. Therefore if a new convert enters the FA, he actually enters into an environment where he can gain knowledge on how to live a life in God based on what he sees from other brothers and sisters in the FA. Besides seeing and studying, the congregation can also get guidance. Guidance can be said as assistance provided when a congregation still does not know how to deal with a case as a believer according to the Word of God. So in these conditions the FA congregation was given suggestions or advice based on the Word of God. Also, of course, the FA congregation or FA management can share their testimonies in dealing with cases that might have similarities so that through this testimony the new congregation can get the determination of faith and try to overcome the problem in the right way. Based on this, it can be assumed that a church member, despite having experienced true repentance, is still blind to living his life according to the truth of the Word if he does not live in a believer's environment that he can see their lives and get input from them so he can walk in the determination of faith in his spiritual life.

The growth of the church can be seen in terms of the increase in branch churches starting from the opening of the FA and the opening of the PI (Evangelism) post and then if it has a relatively settled place of worship, the PI Post can be submitted as a branch Church. With this pattern, the spread of the gospel can also be done effectively and maximally. In the late 20th century Christian researchers discovered that the actual opening of a new church was a very good method of evangelism. So even though the branch church and church building could not be interpreted as progressing the gospel, the opening of the new church could be seen as a result of the spread of the gospel and it was hoped that the new church would continue to spread so that the spread was geographical and the gospel could be heard and bonded in various regions and places. The growth of one's faith in God can also be said as spiritual growth. Any person who was previously in a condition lacked or did not have a living faith in the Lord Jesus as a center of worship. So in other words the person does not have a spiritual life and even lives in accordance with his worldly mind and is far away or minimal in terms of knowledge and knowledge of God. After experiencing repentance and new birth someone begins to believe in Jesus seriously. This means that he began to see the reality that God really exists and does not doubt it. From that moment the person will grow. However, that growth also has a threat that can stop and die. So that growth must be driven by various factors such as worship and carrying out the principles of the truth of the Word of God, such as forgiving, loving, serving and so on. The growth of faith or spiritual growth is indicated by an increase in the realization of the Word of God in life both in terms of attitudes, insights and spiritual gifts experienced by someone.

With the increasing number of churches everywhere and with the growing number of churches the church can be trapped to serve internally. In fact the church really needs to pay attention to the service of the people, even services that are holistic in nature, but if it requires resources and if the church does not carefully maintain balance, the church will feel exhausted and discouraged from carrying out evangelistic responsibilities. On the other hand, servants of the church through cell groups is a pattern that reflects the pattern of service that existed in the early church which in GBI Medan Plaza was called "FA". The core of the FA is the activity of singing praises, worshiping, preaching the Word of God briefly, and praying for one another that reflects the pattern of early church worship activities which are full of atmosphere of togetherness and family. The growth of the church can be seen in terms of the increase in branch churches starting from the opening of the FA and the opening of the PI (Evangelism) post and then if it has a relatively settled place of worship, the PI Post can be submitted as a branch Church. With this pattern, the spread of the gospel can also be done effectively and 
maximally. The opening of the new church can be seen as a result of efforts to spread the gospel and it is hoped that the new church will continue to spread, so that the spread occurs geographically and the gospel can be heard and binded in various regions and places.

\section{Conclusion}

The Church needs to not only carry out evangelism but pay attention to the effectiveness that evangelism is doing well. Insight and knowledge are certainly needed for the development of evangelism, but given that the conditions in the field are very varied to achieve effectiveness, tenacity is needed and carried out in a relatively long period of time and adjustments for adjustments until later a suitable and distinctive model is found for an area . Many God's servants testify that the FA is a place where they have experienced growth. In FA a person can be given trust and an opportunity for individuals to develop capacity in serving and experiencing growth in the spiritual capacity by the Holy Spirit. This is in accordance with the principle of the Word of God that being faithful to small things, God will entrust greater things. Therefore the FA is really a form of service that is very meaningful and produces God's servants in the church. Effective evangelism and the availability of the FA as a place to provide opportunities for prospective servants, the growth of the faith of the church can occur. After experiencing repentance and new birth someone becomes truly convinced of the Lord Jesus and and his growth must be driven by various factors such as worship and carrying out the principles of truth. The growth of faith or spiritual growth is indicated by an increase in the realization of the Word of God in life both in terms of attitudes, insights and spiritual gifts experienced by someone.

\section{References}

[1] W. Stanley Heath, "Mempersiapkan Diri Menjadi Penginjil Pribadi," e-Artikel. http://artikel.sabda.org/mempersiapkan_diri_menjadi_penginjil_pribadi (5/7/2019).

[2] Edgar D. Kamarullah, "Peran serta Jemaat dalam Pelayanan Holistik Gereja Menuju Transformasi," Jurnal Jaffray. https://ojs.sttjaffray.ac.id/index.php/JJV71/article/view/170 $(5 / 7 / 2019)$.

[3] Yakub Tri Handoko, Th.M, "Belajar Penginjilan Dari Yesus (Yohanes 4:3-26)", Reformed Exodus Community, http://rec.or.id/article_900_Belajar-Penginjilan-Dari-Yesus-(Yohanes-4:326)\# (5/7/2019).

[4] Ralph Mahoney dan T.L. Osborn, "Bagaimana Memenangakan Jiwa” Indo Lead, http://lead.sabda.org/11/aug/2005/kepemimpinan_bagaimana_memenangkan_jiwa, (5/7/2019).

[5] Jonathan A. Trisna, "Family Altar," Alkitab Sabda, https://alkitab.sabda.org/resource.

[6] php?topic=182\&res=jpz (5/7/2019). 